\title{
Attachment Theory for Social Work Practice
}


Also by David Howe

SOCIAL WORKERS AND THEIR PRACTICE IN WELFARE BUREAUCRACIES

AN INTRODUCTION TO SOCIAL WORK THEORY

THE CONSUMERS' VIEW OF FAMILY THERAPY

HALF A MILLION WOMEN: Mothers Who Lose Their Children by Adoption (with Phillida Sawbridge and Diana Hinings)

ON BEING A CLIENT: Understanding the Process of Counselling and Psychotherapy 


\title{
Attachment Theory for Social Work Practice
}

\author{
David Howe \\ School of Health and Social Work \\ University of East Anglia \\ Norwich
}

Consultant Editor: Jo Campling

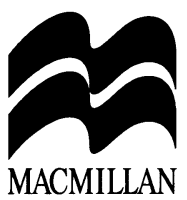


All rights reserved. No reproduction, copy or transmission of this publication may be made without written permission.

No paragraph of this publication may be reproduced, copied or transmitted save with written permission or in accordance with the provisions of the Copyright, Designs and Patents Act 1988, or under the terms of any licence permitting limited copying issued by the Copyright Licensing Agency, 90 Tottenham Court Road, London W1P 9HE.

Any person who does any unauthorised act in relation to this publication may be liable to criminal prosecution and civil claims for damages.

First published 1995 by

MACMILLAN PRESS LTD

Houndmills, Basingstoke, Hampshire RG21 2XS

and London

Companies and representatives

throughout the world

ISBN 978-0-333-62562-0

ISBN 978-1-349-24081-4 (eBook)

DOI 10.1007/978-1-349-24081-4

A catalogue record for this book is available from the British Library.

$\begin{array}{llllllllll}10 & 9 & 8 & 7 & 6 & 5 & 4 & 3 & 2 & 1\end{array}$

$\begin{array}{llllllllll}04 & 03 & 02 & 01 & 00 & 99 & 98 & 97 & 96 & 95\end{array}$

Copy-edited and typeset by Povey-Edmondson

Okehampton and Rochdale, England 


\section{Contents}

1 Social work and social relationships 1

2 Becoming a social being 9

3 The development of social understanding 27

4 Attachment theory and social relationships 45

5 The organisation of experience 71

6 Ainsworth's attachment classification system 78

7 Disturbed social relationships 96

8 Relationships with parents and family 105

9 Relationships with peers $\quad 116$

10 Relationships with self 131

11 Relationships with society 144

12 Relationships with partners 151

13 Relationships with children 160

14 Resilience and the development of protective $\begin{array}{ll}\text { mechanisms } & 178\end{array}$

15 Assessment 188

16 Responses 208

$\begin{array}{ll}\text { Bibliography } & 224\end{array}$

Name index 238

Subject index 242 


\section{Acknowledgements}

My interest in attachment theory and the nature of social relationships in human affairs has been steadily nurtured over the years by my friend and colleague, Diana Hinings. I have lost count of the number of conversations we have had about people and cases, theory and practice, reason and emotion. Her influence pervades every page of the book and I owe her a considerable debt of gratitude. I should also like to take this opportunity to thank Jo Campling. Without her timely prompting and continued encouragement, this particular book would not have been written.

David Howe

The author and publishers would like to thank a number of publishers for their kind permission to reproduce extracts from the following: The Making and Breaking of Affectional Bonds by John Bowlby (Tavistock Publications, 1979); A Secure Base: Clinical Applications of Attachment Theory by John Bowlby (Routledge \& Kegan Paul, 1988); Mate and Stalemate by Janet Mattinson and Ian Sinclair (Blackwell Publishers, 1979); Developing Minds: Challenge and Continuity Across the Life Span by Michael Rutter and Marjorie Rutter (Penguin Books, 1993) copyright (C) Michael Rutter and Marjorie Rutter 1993; Developing Minds: Challenge and Continuity Across the Life Span by Michael and Marjorie Rutter (Basic Books/ HarperCollins Publishers Inc., 1992) copyright (C) Michael Rutter and Marjorie Rutter 1992; Relationship Disturbances in Early Childhood edited by Arnold J. Sameroff and Robert N. Emde (HarperCollins Publishers Inc., 1989) copyright (C) Basic Books Inc. 1989. Every effort has been made to trace all the copyright-holders, but if any have been overlooked the author and publishers will be pleased to make the necessary arrangement at the earliest opportunity. 